\title{
Teaching Reform and Practice of Mathematical Modeling Based on Mathematical Key Competencies
}

\author{
Hao-bin Liu \\ Neijiang Normal University \\ Neijiang, P.R.China \\ Email: njtcliuhb@163.com
}

\author{
Lian-ming Mou* \\ Neijiang Normal University \\ Neijiang, P.R.China \\ *Corresponding author
}

\begin{abstract}
Considering poor basic knowledge, difficult contents and limited class hour of mathematical modeling course, an effective mathematical modeling teaching mode based on mathematical key competencies is put forward by practice. Grade 2013 and Grade 2014 undergraduates from three classes majoring in Mathematics and Applied Mathematics received the same teaching contents, class hour and difficulty level of final exams respectively to compare traditional teaching mode with the teaching mode based on mathematical key competencies. The final exam results and results of mathematical contest in modeling revealed that new teaching mode is suitable for their actual conditions and thus is an effective mathematical modeling teaching mode.
\end{abstract}

Keywords-mathematical key competencies; mathematical modeling; teaching reform; mathematical contest in modeling

\section{INTRODUCTION}

Mathematics links up with all aspects of human society development as a cognitive system. Literature [1] describes how to solve actual problems by mathematical methods, specifically, mathematical modeling, and next, analysis and calculation based on mathematical theories and method. According to Guiding Opinions for Application-oriented Development of Local Colleges and Universities (JF[2015] No.7) [2] jointly issued by Ministry of Education, National Development and Reform Commission, and Ministry of Finance in 2015, local colleges and universities shall set up training model of innovative application-oriented skilled talents to realize application-orientated development. The mathematical modeling course combines theory and practice closely, and can improve consciousness of innovation, teamwork and computer skills of undergraduates and their ability to compose scientific papers. Thus, the course training objective is in line with training objective of key competencies [3] put forward in the document of the Ministry of Education Opinions for Deepening Teaching Reform and Implementation of Basic Morality Education Task, and meets the key competencies development requirements of Chinese undergraduates $[4]$.

In recent years, due to a growing voice of transforming local colleges and universities and training application-oriented talents, many colleges and universities have opened mathematical modeling courses, thus, research and exploration

Fund programs: Comprehensive Reform Pilot Project of Mathematics and Applied Mathematics of the Ministry of Education (ZG0464-6); Mathematical Modeling Teaching Reform (JG201323-249); Mathematical Modeling

Teaching Team (GT14001); "Mathematical Model" Exquisite Resource Sharing Class (01043) on its teaching methods has become a popular research subject [5-8]. Literatures [5-6] analyze problems during mathematical modeling course teaching, put forward reforming teaching materials, teaching content, teaching methods and evaluation methods, and provide some strategies. Literature [7] explores reform of research-based teaching mode based on teaching contents, methods, evaluation modes, teaching evaluation and design of the second classroom. However, the former is not targeted and not specific, while the latter is not universal and difficult to carry out in ordinary colleges and universities. Literature [8] explores teaching reform methods and ways of the mathematics modeling course by generalizing mathematical contests in modeling over the years, and suggests strengthening software teaching and giving more concerns for modeling problems. In 2016, open class on mathematical modeling [9] was opened online, but different quality and class hour limited undergraduates to participating in classroom discussion and practice, so it is difficult to cultivate their key competencies [4] Literature [10] discusses the ways and strategies of educational reform and practice of key competencies, and literature [11] studies the construction of curriculum system based on key competencies of undergraduates. However, both literatures aim at cultivating mathematical key competencies [12-13] of undergraduates. Few research reports emphasize teaching method reform of the mathematical modeling course according to respective curriculum system, basic knowledge of undergraduates and other objective conditions. Literature [14] describes the construction of curriculum system based on mathematical key competencies rather than the implementation of specific curriculum. However, the study indicates the direction of curriculum reform. Considering poor basic knowledge, lacking of study enthusiasm and other conditions of undergraduates in our campus, this paper puts forward, an effective mathematical modeling teaching mode based on mathematical key competencies.

\section{Mathematical Modeling Teaching Mode BASEd on MATHEMATICAL KEY COMPETENCIES}

\section{A. Motive of teaching reform}

Ralph W. Tyler, as an educator, has pointed out that "Essentially, learning takes place through the learner's own experience", i.e. "Learning takes place through the action of the student. It is what he does that he learns, not what the teacher does"[15]. Based on an investigation on undergraduates in our college, Literature [16] indicates that more than half of the 
undergraduates have moderate classroom participation, lack of strong self-learning ability and poor basic knowledge. Thus, it is very necessary to improve their learning initiative and effectiveness.

In order to change this situation, mathematical modeling classroom teaching is profoundly reformed, with an aim to cultivate undergraduates' ability to solve actual problems and improve their mathematical key competences. This requires not only "teach" but also "learn", and the ultimate goal is how to "do", so as to explore an effective teaching mode suitable for characteristics of the mathematical modeling course.

\section{B. Theoretical basis of teaching reform}

The teaching mode reform of mathematical modeling is implemented under the guidance of the education mode "development-centered, unified teaching and learning" [17]. It carries out the thought of key competences whose main contents are to develop "cultural basis, independent development and social participation" of undergraduates, with an aim to cultivate mathematical key competences [12] (mathematical exchange, mathematical modeling, intelligent computing thinking and mathematical emotion). It follows the principle of "learning by doing" through subject competition.

\section{Implementation process of teaching reform}

The teaching process achieves, "mathematical exchange" between teachers and undergraduates and cultivates undergraduates' "mathematical emotion" by cultivating and stimulating their curiosity and enthusiasm. Meanwhile, based on the principle of "learning by doing"[18], more efforts are made to doing, to achieve the purpose of cultivating undergraduates' "mathematical modeling" and "intelligent computing thinking" ability. The specific operational relationship is shown in Fig. 1:

\begin{tabular}{|c|c|c|}
\hline MaC \\
\hline Numerical Simulation and Mathematical \\
Experiment Teaching Center
\end{tabular}

Note:1)PAC: Programming Arena Contest (campus contest)

2) CUEEMCM: China Undergraduate Electrical Engineering Mathematical Contest in Modeling

3) CUMCM: China Undergraduate Mathematical Contest in Modeling

4) MCMQ: Mathematical Contest in Modeling Questions

5) MMAC: Mathematical Modeling Arena Contest (campus selection)

6) MDMLM: May Day Mathematical League in Modeling

Fig. 1. Teaching reform of mathematical modeling based on mathematical key competences

The teaching reform process takes mathematical contests in modeling as a booster and results of undergraduates as a breakthrough point:
First, course assessment reform. To enhance the course participation and mobilize the enthusiasm of undergraduates, the assessment methods will be divided into the following aspects: classroom participation $(20 \%)$, campus competition (20\%), off-campus competition (20\%) and final exam (40\%).

Second, the combination of course teaching and competition training. In order to solve the problems such difficult contents and insufficient class hour, undergraduates receive mathematical software and mathematical modeling method training based on course contents and off-campus competition by centering on classroom teaching and supplemented by off-campus programs.

Third, optimization of course teaching. Teaching materials are mainly those compiled by QY. Jiang[1]. Modeling foundation mainly includes basic knowledge of modeling, elementary model and mathematical software; modeling method mainly introduces optimization model, equation model, probability model and statistical regression model; and comprehensive training mainly includes prediction model, evaluation model, modeling method summary, etc.

Fourth, platform support. The provincial demonstration center serves as a platform to carry out campus competition and the undergraduate quality engineering supports classroom teaching reform, resource construction, teaching team building, etc.

Through the above reform, the cultivation of mathematical key competences ties together through classroom and offcampus practices, classroom teaching and subject competition are closely linked, undergraduates' training and teacher growth are combined, which not only make boring mathematics knowledge close to life and interesting, but also inspire undergraduates to study and use mathematics, thus achieving the effect of application and learning while teaching.

\section{Objectives of teaching reform}

Centering on teaching activities and boosted by modeling competition activities, the teaching reform of mathematical modeling course is performed as follows: exercise the undergraduates' mathematical exchange ability through questions collection contest, improve their programming ability and programming awareness through the programming contest, develop their modeling ability through mathematical contest in modeling, and develop their mathematical emotions by learning and applying mathematics, with an aim to explore a teaching mode meeting actual situation of local teachers colleges of undergraduate course and effectively improving undergraduates' mathematical key competences.

\section{COMPARATIVE STUdy By PRACTICE}

\section{A. Comparison objects}

The undergraduates majoring in Mathematics and Applied Mathematics were taken as research objects: Grade 2013 (193 undergraduates: 51, 69, 70), Grade 2014 (180 undergraduates: $57,61,62$ ) aged from $19-21$ years old basically, percentage of male undergraduates: 28.9\%. Class hours: 51 (34 theoretical class hours, 17 experimental class hours). Teaching materials ${ }^{[1]}$ 
were prepared by QY. Jiang and the teaching chapters are the same.

\section{B. Comparison standards}

In practice, the same test papers were used for the same grade, difficulty of test papers for different grades was similar, and the assessment method was also same. In order to verify effectiveness of teaching reform, final exam results and mathematical modeling competition results were compared and analyzed.

\section{Comparison methods}

\section{1) Traditional teaching mode}

Traditional classroom teaching mode refers to a method that undergraduates are gathered in a fixed classroom and teachers are arranged to teach them knowledge of certain subjects face to face according to fixed teaching plan and teaching time [19]. In terms of traditional teaching mode, more undergraduates can participate in classroom teaching, thus, large amounts of information is disseminated, teaching progress and classroom situation can be easily controlled. As a result, this method is used for most of classroom teaching. The mathematical modeling course is a course for solving actual problems with mathematical knowledge, and involves a wide range of knowledge, complicated contents and practices, which are difficult for many undergraduates.

2) Mathematical modeling teaching mode based on mathematical key competencies

The new teaching mode combines undergraduates' independent learning and explanation under the guidance of a teacher, comments given by the teacher, classroom discussion and teacher's conclusion. During course teaching reform, the implementation process is as follows: (1) centralized teaching of basic concepts; (2) three undergraduates are divided into one group to receive learning tasks and to be guided; (3) classroom presentation of group representatives and group discussion; (4) teacher's comments and conclusion. Extracurricular implementation process is as follows: in the first phase, undergraduates are organized to participated in mathematical contests in modeling to find out actual problems around them, and participated in programming arena contests to improve their computing power; in the second phase, undergraduates are organized to participate in May Day Mathematical League in Modeling and China Undergraduates Mathematical Contest in Modeling to achieve the purpose of studying and applying mathematics; in the third stage, undergraduates are trained again by participating in campus mathematical arena contest in modeling. In different phase, corresponding lectures and trainings shall be provided.

\section{Practice comparison results and analysis}

\section{1) Comparison of final exam results}

In order to compare effect of teaching methods, one grade takes the same final exam papers and different grades take the exam papers with similar difficulty. For statistical final exam results, see Table 1.

TABLE I. STATISTICS OF FINAL EXAM RESULTS OF EACH CLASS

\begin{tabular}{cccccc}
\hline Grade & Class & Headcount & Average & $\begin{array}{c}\text { Standard } \\
\text { deviation }\end{array}$ & $\begin{array}{c}\text { Teaching } \\
\text { method }\end{array}$ \\
\hline \multirow{2}{*}{2013} & 1 & 51 & 77.5 & 7.08 & $\mathrm{Tt}$ \\
& 2 & 69 & 81.8 & 5.34 & $\mathrm{Mt}^{*}$ \\
\hline \multirow{2}{*}{2014} & 1 & 70 & 83.6 & 5.02 & $\mathrm{Mt}^{*}$ \\
& 2 & 57 & 72.6 & 6.77 & $\mathrm{Tt}$ \\
& 3 & 62 & 79.3 & 5.46 & $\mathrm{Mt}^{*}$ \\
\hline
\end{tabular}

*Note: (1)Tt: Traditional teaching, Mt: Mixed teaching;

(2) Grade 2013 undergraduates did not carry out lectures and training associated with the classroom;

(3) Mixed teaching mode refers to mathematical modeling teaching methods based on mathematical key competences;

From the above table, it can be seen that undergraduates receiving mixed teaching obtained significantly better results than these receiving traditional teaching methods, and performance of the former was more stable, indicating that mixed teaching methods are effective.

2) Achievement comparison of mathematical contest in modeling

In order to better compare impact of different teaching methods on undergraduates, the number of award-winning undergraduates who participated in May Day Mathematical League in Modeling, Data Mining Competition, and China Mathematical Contest in Modeling and American Mathematical Contest in Modeling in last two years were counted. As the above contests were group contests (3 undergraduates each group), the players were counted only when they belong to corresponding specialty. In addition, Grade 2013 undergraduates participated in May Day Mathematical League in Modeling, China Undergraduates Mathematical Contest in Modeling in 2015, American Mathematical Contest in Modeling and Data Mining Competition in 2016 respectively. The situation is similar for Grade 2014 undergraduates. The statistical data are shown in the table below:

TABLE II. STATISTICS OF AWARD-WINING UNDERGRADUATES IN MATHEMATICAL CONTEST IN MODELING

\begin{tabular}{|c|c|c|c|c|c|c|c|c|c|c|c|c|c|c|}
\hline \multirow[b]{2}{*}{ Grade } & \multicolumn{3}{|c|}{ MDMLM } & \multicolumn{4}{|c|}{ CUMCM } & \multicolumn{3}{|c|}{ MCM } & \multicolumn{4}{|c|}{ DMC } \\
\hline & $\begin{array}{l}\text { First } \\
\text { prize }\end{array}$ & $\begin{array}{c}\text { Second } \\
\text { prize }\end{array}$ & $\begin{array}{l}\text { Third } \\
\text { prize }\end{array}$ & $\begin{array}{c}\text { National } \\
\text { first } \\
\text { prize }\end{array}$ & $\begin{array}{c}\text { National } \\
\text { second } \\
\text { prize }\end{array}$ & $\begin{array}{c}\text { Provincial } \\
\text { second } \\
\text { prize }\end{array}$ & $\begin{array}{l}\text { Provincial } \\
\text { third prize }\end{array}$ & $\begin{array}{l}\text { Special } \\
\text { prize }\end{array}$ & $\begin{array}{l}\text { First } \\
\text { prize }\end{array}$ & $\begin{array}{l}\text { Second } \\
\text { prize }\end{array}$ & $\begin{array}{l}\text { Special } \\
\text { prize }\end{array}$ & $\begin{array}{l}\text { First } \\
\text { prize }\end{array}$ & $\begin{array}{c}\text { Second } \\
\text { prize }\end{array}$ & $\begin{array}{l}\text { Third } \\
\text { prize }\end{array}$ \\
\hline 2013 & 1 & 2 & 19 & 1 & 1 & 2 & 5 & & 2 & 5 & & & & 2 \\
\hline 2014 & 2 & 17 & 29 & 2 & 4 & 4 & 7 & 1 & 3 & 7 & 1 & 2 & 2 & \\
\hline
\end{tabular}

Note: 1)MDMLM: May Day Mathematical League in Modeling; 2) CUMCM: China Undergraduate Mathematical Contest in Modeling

(3)MCM: The Mathematical Contest in modeling; (4)DMC: Data Mining Competition 
From the above table, it can be seen that, after receiving new teaching mode, more Grade 2014 undergraduates won prizes compared with these receiving traditional teaching mode especially in 2017, Grade 2014 undergraduates won special prize of American Mathematical Contest in Modeling and Data Mining Competition. Besides, according to the results of May Day Mathematical League in Modeling released recently, Grade 2015 undergraduates won 7 first prizes, 19 second prizes and 22 third prizes respectively, indicating that new teaching method is more effective than traditional one and can enhance undergraduates' comprehensive abilities.

\section{CONCLUSION}

In terms of mathematical modeling teaching, many problems such as difficult contents and insufficient class hours have always existed. Most of classroom teaching is cramming education actually. Inevitably, teachers teach a lot, undergraduates rarely assimilate. Through exploration and practice, it is recommended that teachers shall pay attention to the following points during teaching: 1) establish a curriculum system [14] based on key competences of undergraduates; 2) mobilize enthusiasm of undergraduates, especially their classroom participation and before \& after campus involvement, and make more efforts to allow them to know how to "do", thus making classroom teaching effective [20]; 3) give theoretical knowledge a carrier by combining real life or practical cases; 4) actively carry out the curriculum-related practical activities, consciously create a strong atmosphere of competition during teaching and stimulate undergraduates' passion for learning.

\section{REFERENCES}

[1] QY. Jiang, JX. Xie, J. Ye, Mathematical model (Fourth Edition).Higher Education Press, 2010(in Chinese)

[2] teaches [2015]7 file, http://www.moe.gov.cn/

[3] Editorial Department of people's education. "Key Competencies: reconstructing the future of education," People's Education, A7,pp.77,2015(in Chinese)

[4] CD. Lin, "To Construct Sinicized Core Competencies and Values for Student Development," Journal of Beijing Normal University (Social Sciences), A259, pp.66-73, January 2017(in Chinese)
[5] J. Pu, ZL. Zhang, SC. Li, XJ. Fu, "Discussion on the training and innovation of mathematical modeling for students of science and Engineering in local comprehensive universities," China University Teaching, A7,pp.56-58,2014(in Chinese)

[6] LL. Duan, "Teaching reform of mathematical modeling course," Education and Vocation, A753,pp.140-142,May 2013 (in Chinese)

[7] J. Xiao, Q. Gong, "Reform and practice of research teaching in mathematical model and mathematical experiment course," Education Teaching Forum, A19, pp.81-82,May 2016(in Chinese)

[8] Y. Lv, GM. Jiang, "The Research on Mathematical Modeling Teaching Reform," Journal of Southwest China Normal University(Natural Science Edition), Vol40.A12, pp.173-175, December 2015 (in Chinese)

[9] QY. Jiang, etc, Tsinghua University open class: mathematical model, http://open.163.com/cuvocw/

[10] Y. jiang, T. Xin, X. Liu, CD. Lin, "Practice and strategy of education reform based on Key Competencies," Journal of the Chinese Society of Education, A6, pp.29-32,June 2016 (in Chinese)

[11] LM. Zhu, "Construction of mathematical Key Competencies system based on deepening curriculum reform," Journal of the Chinese Society of Education, A5, pp.76-80, May 2016 (in Chinese)

[12] JF. Cai, B. Xu, "On the Key Competencies of Mathematical Literacy," Global Education, Vol45.A352,pp.3-12, November 2016 (in Chinese)

[13] YP. Ma, "Several issue about the Core Literacy of mathematics," Curriculum, Teaching Material and Method, Vol35.A9, pp.3639,September 2015 (in Chinese)

[14] T. Xin, Y. Jiang, YH. Wang, "Curriculum system constitution Based on Students' key competencies,"Journal of Beijing Normal University(Social Sciences), A241,pp.5-11,January 2014 (in Chinese)

[15] Ralph-Taylor. Basic principles of curriculum and instruction, Beijing Light Industry Press, 2014 (in Chinese)

[16] H. Zhang, M. Zhang, Q. Chen, XM. Wang, "Effective Strategies for college Student' Classroom Learning Participation," Journal of Neijiang Normal University, Vol27.A8,pp.90-95,August 2012(in Chinese)

[17] L. Zeng, etc, "Research on cultivation Mode with the Centre of Development and the Unification of Teaching, Learning and Doing," Research in Teaching, A391, pp.149-154, August 2012 (in Chinese)

[18] JW. Zhang, YQ. Sun, "From learning by Doing to Constructivism: Exploring the Path of learning theories," Theory and Practice of Education,Vol26.A4,pp.35-39, April 2006 (in Chinese)

[19] XY. Deng, "Research on the combination of three classroom teaching methods," China University Teaching,A7,pp.62-63,July 2011(in Chinese)

[20] H. Ding, GF. Cui, YN. Wang, "Exploration and Practice of Effective Teaching of Public Mathematics in Technical Application University," Heilongjiang Researches on Higher Education, A7,pp.173176,September 2016 (in Chinese) 